\title{
A STUDY FOR SUITABILITY OF QUARRY DUST FROM DIFFERENT MINERALOGICAL SOURCES FOR REPLACEMENT OF FINE AGGREGATE
}

\author{
Abhishek Mathur ${ }^{1}$, Pradeep K. Goyal ${ }^{2}$ \\ ${ }^{I}$ P.G Student. of Structural Engineering, Rajasthan Technical University, Kota Raj. India \\ ${ }^{2}$ Associate Professor, Dept. of Civil Engineering, Govt. Engineering College, Ajmer, Raj. India
}

\begin{abstract}
Incorporation of industrial waste in concrete. A number of studies on sustainable use of various type of quarry dust in concrete as a partial replacement of sand had been performed. In this the influence of three different types of quarry dust Granite, Limestone and dolomite (confirming to zone II of IS: 383) was studied taking the ratio of coarse aggregate, cement and water as fixed. Test for mechanical and durability properties of concrete were performed. Results shows that sample concrete with Granite as partial replacement of fine aggregated provide more compressive strength after 28 day curing, than other two mixes. The effect of shape and texture increases the interlocking of particles meanwhile reduces the workability of concrete. For same slump of concrete super plasticizer are to be used.
\end{abstract}

Keywords: Aggregate; Granite; Dolomite; Mechanical properties; Quarry dust

\section{INTRODUCTION}

Quarry dust is a waste product generated from blasting and dressing of stone from parent rock. Its property mainly depends upon the rock from it originated. Its mineralogical characteristic and texture depends upon the stratification of parent rock remains same properties such as shape, size, water absorption changes due to blasting and crushing. The physical and chemical properties of stone influence its use in conventional concrete.

Coarse aggregate provides mass to concrete .The voids of coarse aggregate are occupied with sand and cement slurry. Partial replacement of natural sand as quarry dust increases compressive .The specific surface area of fine aggregate increases by incorporating quarry dust require high cement paste volume and workability of mix decreases as the particles of quarry dust are of irregular shape. as reported in many studies had been reported the influence of coarse aggregate having different mineralogical composition. This the influence of crushed sand from different mineralogical sources and its effect on properties of concrete as partial replacement of fine aggregate as shown in Fig.1.

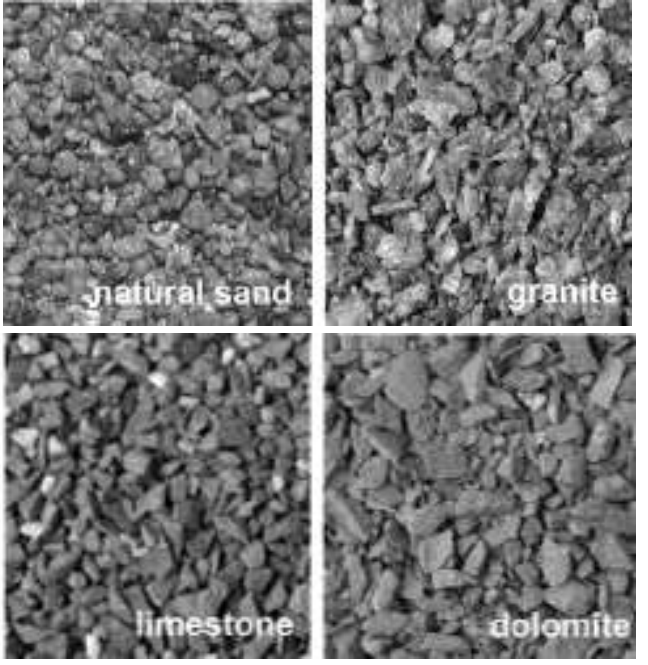

Fig.1: Photographs of used sands.

Sieve analysis for various samples and properties of various samples of quarry dust are given in Tables 1-2.

Table1: Sieve analysis for various samples of quarry dust

\begin{tabular}{|l|l|l|l|l|}
\hline \multicolumn{5}{|l}{ Cumulative \% Passing } \\
\hline \multirow{2}{*}{ Sieve } & Siliceous & Granite & Limestone & Dolomite \\
\cline { 2 - 5 } & (NS) & (GS) & (LS) & (DS) \\
\hline $4.75 \mathrm{~mm}$ & 99 & 100 & 94 & 97 \\
\hline $2.36 \mathrm{~mm}$ & 88 & 76 & 72 & 61 \\
\hline $1.18 \mathrm{~mm}$ & 49 & 54 & 59 & 57 \\
\hline $600 \mathrm{mic}$ & 26 & 36 & 52 & 47 \\
\hline $300 \mathrm{mic}$ & 4 & 22 & 19 & 29 \\
\hline $150 \mathrm{mic}$ & 0 & 8 & 9 & 18 \\
\hline
\end{tabular}


Table 2: Properties of various samples of quarry dust

\begin{tabular}{|l|l|l|l|l|}
\hline \multirow{2}{*}{ Properties } & Siliceous & Granite & Limestone & Dolomite \\
\cline { 2 - 5 } & (NS) & (GS) & (LS) & $(\mathrm{DS})$ \\
\hline $\begin{array}{l}\text { Silt } \\
\text { content }\end{array}$ & 0 & 10.7 & 10.6 & 13.3 \\
\hline $\begin{array}{l}\text { Finesss } \\
\text { modulus }\end{array}$ & 3.34 & 3.15 & 3.48 & 3.38 \\
\hline Sp.Gr & 2.64 & 2.69 & 2.68 & 2.77 \\
\hline Shape & Rounded & Angular & Angular & Elongated \\
\hline $\begin{array}{l}\text { Surface } \\
\text { texture }\end{array}$ & Smooth & Crystalline & Rough & Rough \\
\hline
\end{tabular}

For this study two mixes of concrete is designed using IS 10262:2009 and the ratio for cement, fine aggregate and coarse aggregate is obtained for water cement ratio of 0.43 . The quantity required for fine aggregate was replace by sand(S), Granite(G), Dolomite(D) and Lime stone (L). The Mix proportion are represented as given in Table 3.

Table 3: Mix Proportions

\begin{tabular}{|l|l|l|l|l|l|l|l|l|}
\hline Mixture & S-530 & G-530 & G-485 & G-450 & D-485 & L-485 & L-450 & D-450 \\
\hline Cement & 530 & 530 & 485 & 450 & 485 & 485 & 450 & 450 \\
\hline Water & 160 & 160 & 160 & 160 & 169 & 168 & 160 & 175 \\
\hline F.A & 660 & 660 & 698 & 727 & 720 & 702 & 736 & 724 \\
\hline C.A & 1030 & 1030 & 1030 & 1030 & 1030 & 1030 & 1030 & 1030 \\
\hline $\begin{array}{l}\text { Super plasticizer (\% } \\
\text { by mass of cement) }\end{array}$ & 0.67 & 0.89 & 0.89 & 0.89 & 0.89 & 0.89 & 0.89 & 0.89 \\
\hline w/c ratio & 0.43 & 0.43 & 0.43 & 0.43 & 0.43 & 0.43 & 0.43 & 0.4 .3 \\
\hline Slump (mm) & 180 & 170 & 160 & 120 & 80 & 175 & 140 & 80 \\
\hline
\end{tabular}

\section{EXPERIMENTAL METHODS}

Following procedure is adopted for carried out this present study.

\subsection{Materials}

JK Lakshmi Cement (OPC 43 grade) was used Granite crushed stone of $20 \mathrm{~mm}$ and $12.5 \mathrm{~mm}(2: 1)$ was used as coarse aggregate. Superplastizer Conplast SP 337 having Specific gravity: 1.18 to 1.20 at $270 \mathrm{C}$ and Chloride content is nil. Fine aggregates having similar fines modulus confirming to zone II of IS: 383 were used .For reference Natural sand has (NS) have smooth and rounded particle is considered. Table 1 and Table 2 gives the grading and physical properties of granite, limestone and dolomite. Silt content is also observed higher than permissible limit.

\subsection{Mixture Proportions}

Concrete mixes were designed using all sources of fine aggregate Table 2 represent the proportion of mix and corresponding slumps for each mix. Two samples were made to analysis the effect of quarry dust with natural sand. Cement content is taken on higher side. Six sample were to study the effect if all three mineralogical aggregate using cement content 450 and $485 \mathrm{~kg} / \mathrm{m} 3$ keeping C.A and water content constant.

\subsection{Testing}

For determining compressive strength, cube of dimension $150 \mathrm{~mm} \times 150 \mathrm{~mm} \times 150 \mathrm{~mm}$ were casted and after 28 day curing, their compressive strength is observed, To determine the split tensile test, cylinder of dimension $150 \mathrm{~mm}$ dia. and height $300 \mathrm{~mm}$ are casted and after 28 day curing they are applied under axial load such that longitudinal axis of cylinder is under the axis of load. Flexure strength is observed by casting prism of $150 \mathrm{~mm} \times 150 \mathrm{mmx} 700 \mathrm{~mm}$ and using third point loading system.

\section{RESULTS AND DISCUSSION}

\subsection{Fresh Concrete Properties}

For S-530 and G-530 concretes, good slum was observed. The use of super plasticizer increase the workability to obtain required slump .For mix with granite dust requires a higher quantity of super plasticizer to obtain same workability. Same observation was for lower cement content. workability greatly reduced after $25 \mathrm{~min}$. Mix having Dolomite shows poor fresh behaviour. The D-485 mixture has lowest value of slump and D-450 have very poor cohesiveness making concrete not workable.

\subsection{Hardened Concrete Properties}

\subsubsection{Influence of shape and surface texture}

Fig. 2 shows the compressive strength of crushed sand concrete and natural sand. G-530 shows highest compressive strength than S-530 concrete mix for all days of curing. The surface of fine aggregate and a lager influence on hydration of cement. The G-530 mixture has higher strength values than the S-530 mixture for flexural strength tests of the mortar fraction. The progress of the transition zone could be accredited to the rough texture of granite sand, which increases the aggregate interlocking with the cement paste. Planes weak cleavage due to mica in granite rocks results initiation of failure in the coarse 
aggregate. Fig.2 shows the variation of compressive strength with number of days.

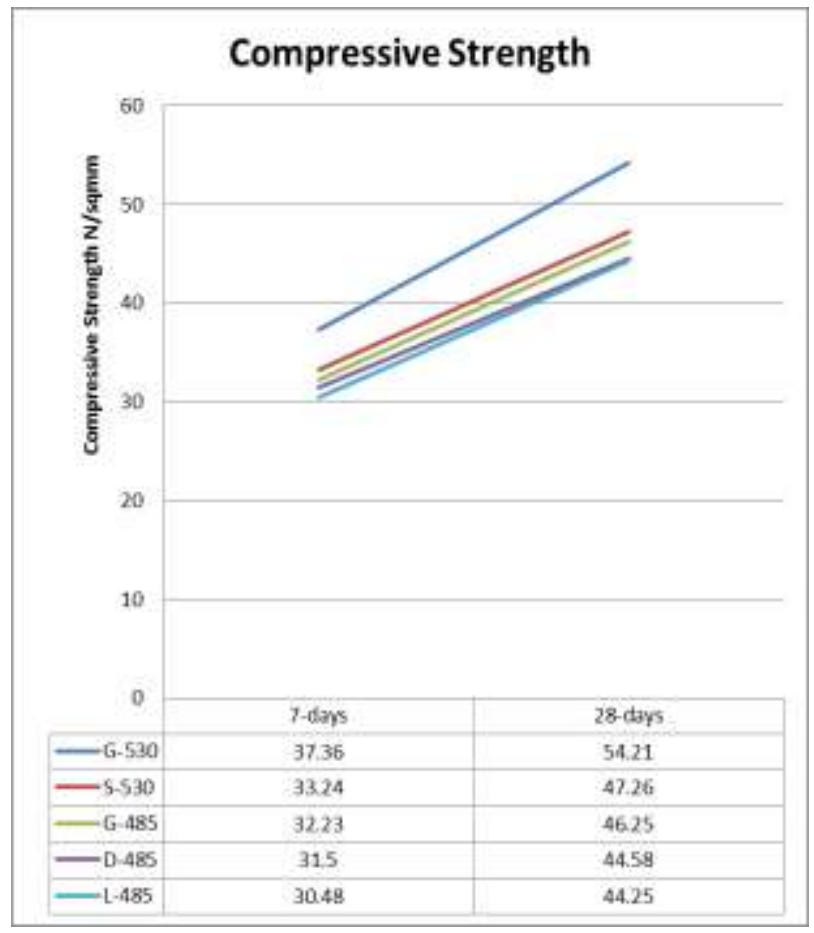

Fig. 2. Development of compressive strength of concrete with crushed sands from different sources.



Fig. 3. Development of split tensile strength of concrete with crushed sands from different sources.

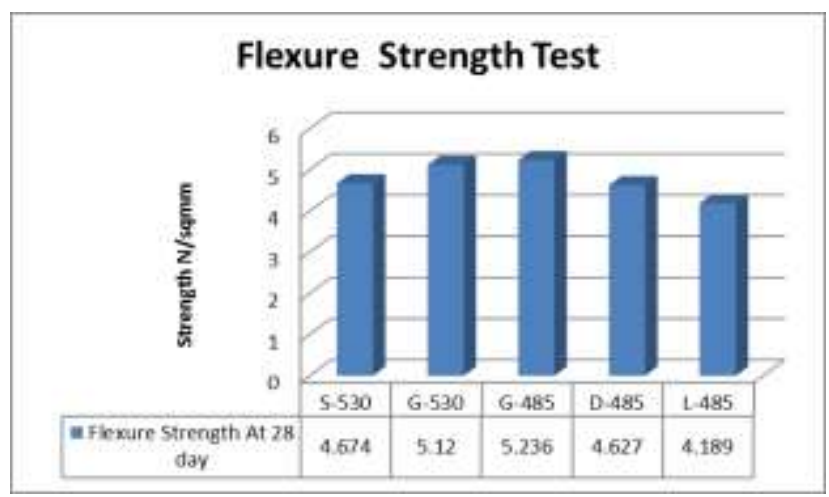

Fig. 4. Development of flexure strength of concrete with crushed sands from different sources.

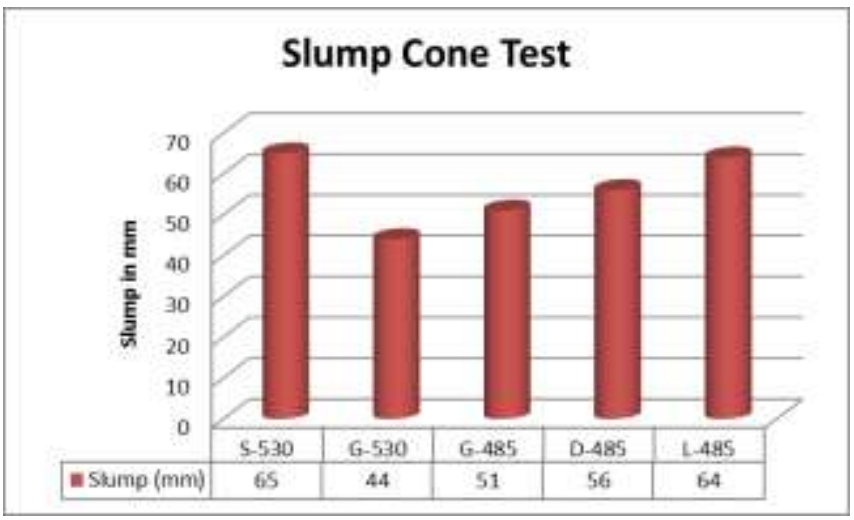

Fig. 5. Comparison of result for slump cone test of concrete with crushed sands from different sources.



Fig. 6. Comparis on of result for compaction factor test of concrete with crushed sands from different sources.

\section{CONCLUSION}

The following conclusions are made from the present as mentioned below.

1) High Strength concrete can be made by using quarry dust in replacement of natural sand.

2) Quarry dust requires a higher quantity of super plasticizer to improve workability and to overcome the adverse shape and texture of particles.

3) The need of optimal doses for super plasticizer for each type of sand and cement content in the mixture to be studied.

4) Granite quarry dust is most advantageous for replacement of natural

5) Texture of crushed sand particles have an important effect of strength of concrete.

\section{REFERENCES}

[1] Binici H, Kaplan H, Y1lmaz S. Influence of marble and limestone dusts as additives on some mechanical properties of concrete. Sci Res 2007; Essay

[2] BaharDemirel, "The effect of the using waste marble dust as fine sand on the mechanical properties of the concrete," International Journal of

the Physical Sciences, 5 (9), pp 1372-1380, 2010.

[3] ACI Committee 363, State-of-the-Art Report on High Strength Concrete. Manual of Concrete Practice, ACI, Farmington Hill, USA, 1984. 
[4] J. Kim, C. Lee, C. Park, S. Eo, The fracture characteristics of crushed limestone sand concrete, Cem. Concr. Res. 27 (11) (1997) 1719-1729

[5] Mehta, P. K. "Greening of the Concrete Industry for Sustainable Development", Concrete. Int., 24: (7): 2327,2002.

[6] MS.Shetty ,Concrete Technology- S.Chand

[7] HanifiBinici, Hasan Kaplan and SalihYilmaz, "Influence of marble and limestone dusts as additives on some mechanical properties of concrete," Scientific Research and Essay, 2(9), pp 372379, 2007.

[8] Alyamac KE, Ince R. "A preliminary concrete mix design for SCC with marble powders." Const. Build. Mat.,23(3): 1201-1210, 2009.

[9] Dr. Anurag Mishra, Mr. Rajesh Gupta, "Utilization of Marble Slurry in Construction Materials". Workshop on gainful utilization of Marble

Slurry and other stone waste.

[10] IS: 8112-1989. Specifications for 43-Grade Portland cement. New Delhi, India: Bureau of Indian Standards.

[11] IS: 383-1970. Specifications for coarse and fine aggregates from Natural sources for concrete. New Delhi, India: Bureau of Indian Standards.

[12] IS: 10262-2009. Recommended guidelines for concrete mix design. New Delhi, India: Bureau of Indian Standards.

[13] IS: 1199-1959. Indian standard methods of sampling and analysis of concrete. New Delhi, India: BIS

[14] IS: 516-1959. Indian standard code of practicemethods of test for strength of concrete. New Delhi, India: BIS 